Wir sind der Auffassung, dass mit diesem Ausdruck das Reizmengengesetz für die Reaktionsholzbildung angewandt werden kann. Bei Zellenzahl $=\mathbf{3}$ ist die Reizschwelle angedeutet, das heisst die Reizmenge, die zur Umstimmung der Kambiumzellen notwendig ist. Sie liegt in der Grössenordnung von $1 \times 10^{6} \mathrm{~cm} \times \mathrm{sec}^{-1}$.

Unsere Versuche zeigen die Möglichkeit auf, mit Hilfe der Massenbeschleunigung die Differenzierung der Holzzellen gerichtet zu beeinflussen und damit einen Einblick in die Kambiumphysiologie und den Wuchsstoffhaushalt ${ }^{2}$ zu gewinnen.

Summary. In leaning stems, reaction wood can be formed as a response to gravitation stimulus. In seedlings of Aesculus hippocastanum, reaction wood formation could likewise be stimulated by centrifugation. This proved the differentiation of wood cells to be affected by mass acceleration. The reaction wood formation is related quantitatively to mass acceleration $b$ and time $t$, the formation of reaction wood being described by quantitative stimuli law as $\sqrt[3]{b} \times t$. The threshold of stimulation lies in the dimension $\sqrt[3]{b} \times t=1 \times 10^{6} \mathrm{~cm} \times \mathrm{sec}^{-1}$. The arrangement of the experiments permits a direct approach to cambium physiology and the following differentiation of wood cells.

\section{G. CASPERSON}

Institut für Faserstoff-Forschung der Deutschen Akademie der Wissenschatten zu Berlin, Teltow-Seehof (DDR), 24. Juli 1967

\title{
Isolation and Antiviral Activity of the Gymnemic Acids
}

Of current interest in our program ${ }^{\mathbf{1 , 2}}$ in the identification of biologically active compounds from Gymnema sylvestre R.Br. (Asclepiadaceae) leaves is 'gymnemic acid', the antisweet principle of the plant ${ }^{3,4}$. The present report describes the isolation of compounds with significant antiviral activity from this principle. These findings assume added significance based upon the recent advance in the chemistry of gymnemic acid presented from Professor REICHSTEIN's laboratories ${ }^{5}$.

Crude gymnemic acid mixture was obtained by mineral acid precipitation ${ }^{3}$ from the aqueous extract of the leaves. The preferred procedure to resolve this acid mixture was to plate it from a methanol solution on silica gel, and extract with chloroform and ethyl acetate in a Soxhlet extractor. The ethyl acetate extractive was then chromatographed over silica gel with elution by increasing proportions of acetone in ethyl acetate. Four principal acids have been isolated by this procedure and named gymnemic acids A-D based upon their order of elution.

In order to examine gymnemic acid fractions and to monitor their separations, 4 silica gel thin-layer chromatographic (TLC) systems ${ }^{*}$ were developed. Gymnemic acids A-C, homogeneous in the 4 TLC systems, were obtained by individual rechromatography over silica gel employing ethyl acetate for elution and recrystallization from ethyl acetate. Homogeneous acid $D$ was secured by reversed phase chromatography over Teflon- 6 at $17^{\circ} \mathrm{C}$ with elution by the aqueous phase of $n$-butanol-water-methanol $(10: 10: 1)$ while the organic layer served as the stationary phase. As an average of 20 determinations, $\mathrm{Rf}$ values for these gymnemic acids in TLC system I were: A, $0.60 \pm 0.07 ; \mathrm{B}, 0.49 \pm 0.04 ; \mathrm{C}, 0.30 \pm 0.01$ and $\mathrm{D}$, $0.25 \pm 0.02$.

Gymnemic acid A, isolated by STöckIIN, WEIss and REICHSTEIN ${ }^{5}$, consists of 4 acids $\mathrm{A}_{1}-\mathrm{A}_{4}$ based upon silica gel TLC in butyl formate-methyl ethyl ketone-formic acid-water $(5: 3: 1: 1)$ (system V). Direct TLC comparison of our gymnemic acids $A-D$ with acid $A\left(A_{1}-A_{4}\right)$ isolated by the Swiss investigators ${ }^{7}$ established that in TLC systems $I-V$ our acids $A$ and $B$ are identical to their acids $A_{1}$ and $A_{2}$. However, acids $C$ and $D$ do not correspond to acids $A_{3}$ and $A_{4}$. Our acids $A$ and $B$, in agreement with gymnemic acid $A\left(A_{1}-A_{4}\right)$ isolated by RerchsteIN's group, contain glucuronic acid as the sole sugar residue.
In contrast, our gymnemic acids $\mathrm{C}$ and $\mathrm{D}$ contain both glucuronic acid and glucose as shown by acidic hydrolysis, chromatography ${ }^{8}$ and isolation". Ferulic acid has been indicated in our studies in alkaline hydrolysates of acid $\mathrm{C}$

Table I. Effects of gymnemic acids against influenza $\left(\mathrm{A}_{2} / \mathrm{Ann}\right.$ Arbor $/ 6 / 60)$ virus in vitro

\begin{tabular}{|c|c|c|c|}
\hline \multirow[t]{2}{*}{ Sample } & Virus yield & & Inhibition \\
\hline & \multicolumn{3}{|c|}{ Hemagglutinin Infectivity } \\
\hline Control & 256 & 7.3 & none \\
\hline Crude acid mixture & 64 & 5.0 & some \\
\hline Ethyl acetate acids & 8 & 4.5 & moderate \\
\hline Gymnemic acid $A$ & 0 & 2.5 & good \\
\hline B & 8 & 4.3 & moderate \\
\hline $\mathrm{C}$ & 256 & 7.0 & none \\
\hline $\mathrm{D}$ & 512 & 7.5 & none \\
\hline
\end{tabular}

1 P. E. Manni and J. E. Sinshetmer, J. Pharm. Sci. 54, 1541 (1965). 2 J. E. Sinsheimer and H. M. McIlhenny, J. Pharm. Sci. 56, 732 (1967).

${ }^{3}$ D. Hooper, Pharm. J. 77, 867 (1887).

4 R. M. Warren and C. Pfaffmann, J. appl. Physiol. 14, 40 (1959).

5 W. Stöcklin, E. Werss and T. Reichstein, Helv, chim. Acta 50, 474 (1967); W. StöckLIN, Helv. chim. Acta 50, 491 (1967).

6 The TLC systems: I, chloroform-formic acid-methanol-t-butanol $\left(4: 1: 1: 1\right.$, aged for $3 \mathrm{~h}$ at $\left.27^{\circ} \mathrm{C}\right)$; II, chloroform-acetic acidmethanol $(5: 1: 1)$; III, iso-amyl alcohol-ammonium hydroxidechloroform-t-butanol $(5: 2: 1: 1)$ and IV, iso-amyl alcohol-ammonium hydroxide-iso-propanol $(3: 2: 1)$. A modified LIEBERMANNBURCHARD spray reagent [I. Belic, Nature 178,538 (1956)] was used as the chromogen.

"We are grateful to Prof. T. Reichstein and Dr. W. Stöcklin, University of Basel, for these reference samples.

${ }^{8}$ I. Sмiтн, Chromatographic and Electrophoretic Techniques (Interscience, New York 1960), vol. 1, p. 246.

${ }^{9}$ H. M. McIlnensy, Ph.D. Dissertation, University of Michigan (1966). 
Table II. Effect of gymnemic acids against PRs influenza $A$ virus in mice

\begin{tabular}{|c|c|c|c|c|c|}
\hline Sample & $\begin{array}{l}\text { Dose } \\
\left(\mathrm{mg} / \mathrm{kg} / \mathrm{day}^{\mathrm{B}}\right)\end{array}$ & $\begin{array}{l}\text { Injection } \\
\text { route }\end{array}$ & $\begin{array}{l}\text { Average } \\
\text { Treated }\end{array}$ & $\begin{array}{l}\text { n score } \\
\text { Control }\end{array}$ & $\begin{array}{l}\% \text { decrease in } \\
\text { lung lesion score }\end{array}$ \\
\hline Crude acid mixture & $250 \times 1,100 \times 2^{b}, 75 \times 1$ & i.p. & 1.1 & 1.5 & 27 \\
\hline Ethyl acetate acids & $\begin{array}{l}250 \times 1,100 \times 2^{b}, 75 \times 1 \\
75\end{array}$ & $\begin{array}{l}\text { i.p. } \\
\text { s.c. }\end{array}$ & $\begin{array}{l}0.6 \\
2.8 \\
1.9\end{array}$ & $\begin{array}{l}1.5 \\
3.9 \\
2.2\end{array}$ & $\begin{array}{l}60 \\
28 \\
14\end{array}$ \\
\hline Gymnemic acid A & $\begin{array}{l}75 \\
75\end{array}$ & $\begin{array}{l}\text { i.p. } \\
\text { s.c. }\end{array}$ & $\begin{array}{l}2.5 \\
1.8\end{array}$ & $\begin{array}{l}3.8 \\
2.2\end{array}$ & $\begin{array}{l}34 \\
18\end{array}$ \\
\hline
\end{tabular}

- Starting day $(D+1)$ after virus administration, continuing through $(D+4), v$ Daily dose reduced because of toxicity.

in 2 silica gel TLC systems ${ }^{10}$. However, acid C, m.p. $215-220^{\circ}$ (decomp.), UV (methanol) $\lambda_{\max } 201 \mathrm{~nm}(\mathrm{a} 8.18)$ (Anal.-Found ${ }^{11}$ : C, 49.4; H, 6.7\%) and acid D, m.p. $210-220^{\circ}$ (decomp.), UV (methanol) $\lambda_{\max } 201 \mathrm{~nm}$ (a 9.69), (Anal-Found ${ }^{11}$ : C, 57.5; H, 7.7\%) produce IR-spectra remarkably similar to that previously reported ${ }^{5}$ for gymnemic acid $\mathrm{A}_{1}$.

Table I shows gymnemic acid fractions tested against influenza virus in vitro. Tube cultures of primary chick kidney cells were treated immediately before inoculation with the Ann Arbor 6/60 strain of Asian influenza virus at an estimated multiplicity of $10: 1$ in order to obtain a single cycle of viral growth. Preliminary tests showed that none of the gymnemic acid preparations had direct virucidal activity at the levels used. All acid fractions, as they were not significantly different in toxicity, were added at a final concentration of $0.5 \mathrm{mg} / \mathrm{ml}$, the maximum tolerated. After $48 \mathrm{~h}$, measurements were made of the yield of viral hemagglutinin and infectivity. Hemagglutinin yield is expressed as the reciprocal of the highest dilution giving a positive pattern with chicken erythrocytes, while infectivity is given as the negative $\log _{10}$ of the $50 \%$ infectious dose in eggs. Some inhibition was demonstrable in the crude gymnemic acid fraction with moderate inhibitions obtained with ethyl acetate extract and with gymnemic acid B. Good inhibition was seen with gymnemic acid $A$ while none was observable with acids $C$ and $D$.

Since gymnemic acid A showed the greatest activity, it was studied further in vitro. When the multiplicity of the virus challenge was reduced, the effectiveness of the inhibition increased, as judged by both cytopathology and hemagglutinin yield. In a study of time of treatment, gymnemic acid A was equally effective when added immediately before or $1 \mathrm{~h}$ after virus inoculation. Drug added $2 \mathrm{~h}$ after virus was somewhat less effective, while drug addition at $3 \mathrm{~h}$ was noticeably less effective but still inhibitory in terms of all 3 parameters. Thus, at least 1 site of action of gymnemic acids is associated with relatively early events in the virus infectious cycle. In this regard, these nitrogen-free compounds are similar to the antipenetrant antiviral amines ${ }^{12}$. The antiviral spectrum of gymnemic acid A was sought by further testing. When acid $A$ at a final concentration of $0.5 \mathrm{mg} / \mathrm{ml}$ was added to LLC MK $\mathrm{M}_{2}$ cells immediately before a high multiplicity of ECHO 28 (or rhino-virus 1) to minimize the effect of a secondary growth cycle of the virus, there was a $1.6 \mathrm{log}$ inhibition of virus yield. No activity was seen against poliovirus in primary monkey kidney cells.

Preliminary tests were conducted to evaluate the drug's effectiveness in the whole animal to assess properly its potential as an antiviral agent. Determination of toxicity for mice indicated an acute $\mathrm{LD}_{50}$ of approximately 500 $\mathrm{mg} / \mathrm{kg}$ given as a single i.p. dose. Anti-influenza activity of gymnemic acid fractions in mice is shown in Table II. For in vivo studies A/PR8, a strain of influenza virus most highly adapted to mice, was used. Swiss Webster mice in groups of 10 were exposed to aerosols of PR8infected mouse lungs at a challenge level equivalent to approximately $10 \mathrm{LD}_{50}$ 's. Treatment was started the day after virus inoculation, the routes and daily dose rates as indicated. Control mice were treated with equal volumes of buffered saline, alone or containing $10 \%$ ethanol. On the fifth day, mice were sacrificed and evaluated for lung damage, with scores of +1 for each $25 \%$ of consolidation and +5 for spontaneous death. Significant activity ( $>25 \%$ decrease in influenzal lung lesion score compared to simultaneously exposed, placebo-treated controls) ${ }^{13}$ was seen with i.p. administration; s.c. treatment appeared less effective ${ }^{14}$.

Zusammentassung. Aus den Blättern von Gymnema sylvestre wurden 4 Gymneasäuren (A, B, C und D) isoliert. Die Antivirusaktivität der Säuren $A$ und $B$ wurde geprüft.

J. E. Sinsheimer, G. Subba Rao, H. M. MCILHENNY, R. V. SMITh, H, F. MAAsSAB and $K$, W. Cochran

College of Pharmacy, The University of Michigan and Department of Epidemiology and Virus Laboratory, School of Public Health, The University of Michigan, Ann Arbor (Michigan USA), 30 October 7967.

${ }^{10}$ J. M. BoвBrtr, Thin-Layer Chromatography (Reinhold, New York 1963), p. 138.

${ }^{11}$ Analysis performed on a F \& M CHN Analyzer Model 180 .

12 W. L. Davies, R. R. Grunert, R. F. Haff, J. M. McGahen, E. M. Neumayer, M. Paulshock, J. C. Watrs, T. R. Wood, E. C. Hermann and C. E. Hoffuan, Science 144, 862 (1964). K. W. Cochran, H. F. MaAssab, T. Tsunoda and B. S. Berlin, Ann. N.Y. Acad. Sci. 130, 432 (1965); R. D. Fletcher, J. E. Hirscirmetid and M. ForbFs, Nature 207, 664 (1965).

13 R. Pollikoff, M. Liberman, K. W. Cocitran and A. M. Pascale, Antimicrob. Ag. Chemother. 1965, 561 (1966).

14 This investigation was supported in part by U.S. Army Medical Research contract No. DA-49-193-MD-2066, and by U.S. Public Health Service grants No. AM 06224-04 and AI 05876-03. Presented in part before the 1967 annual meeting of the American Society for Microbiology. 